\title{
Vegetable by-products in the European food legislative framework
}

\author{
Nada Knežević*, Jasmina Ranilović, Tanja Cvetković, Slavka Grbavac, Marina Palfi \\ Podravka Inc., Research and Development, Ante Starčevića 32, 48000 Koprivnica, Croatia \\ *Corresponding author: nada.knezevic@podravka.hr
}

\begin{abstract}
Vegetable by-products are a source of many useful bioactive compounds, dietary fiber, fatty acids and proteins that have a great potential in the development of new food products and the promotion of the circular economy and sustainability.

Considering processed pepper by-products as an example, the aim of this paper is to provide an overview of EU food legislation that should be taken into account before placing such products on the market, as well as of the voluntary labeling of functional, nutritional and sustainability benefits important for consumers.
\end{abstract}

Keywords: pepper, vegetable by-products, food legislation, circular economy, consumers

\section{Introduction}

Scientific research indicates that the consequences of climate change are clear and unambiguous and that they significantly affect our lives (NASA, 2021). Soil cultivation practices, deforestation and the burning of fossil fuels during the course of human activities greatly contribute to the increase of greenhouse gases in the Earth's atmosphere. For future quality of life there is a need for continuous sound scientific observations, and for mitigation, adaptation, and sustainability strategies. The United Nations has proposed a shift towards a circular economy (UN, 2021). In March 2020, the European Commission adopted a new circular economy action plan (CEAP) from how products are designed and processed to sustainable consumption in order to prevent losses though wastage and preserve resources (European Commission, 2020). Experts in bioeconomy clusters support a bio-based product design that facilitates durability, reuse, repair, recycling, or biodegradability (Stegmann et al., 2020). Aiming at this, all stakeholders (regulators, agricultural and food producers, scientists, traders, consumers) need to collaborate. However, consumer interest and involvement in the circular economy are low, since most consumers do not understand the definition of the circular economy (Sijtsema et al., 2020). Authors concluded that including consumers in the co-creation of innovative food products could raise their awareness of the role of consumers in the circular economy. On the other hand, consumers are not aware that food consumption accounts for 20-30\% of the negative impact on the environment (Notarnicola et al., 2017). Consequently, the food industry needs to change its approach to the design of new products, assessing each segment of the supply chain, to be more effective with a less negative environmental footprint. Exploitation of the by-products of food processing and their transformation into new, higher value food products are a platform for innovation and can attract new health- and sustainability-conscious consumers.

By-products from the processing of raw vegetables usually contain significant amounts of bioactive and nutritional compounds such as proteins, dietary fiber, polysaccharides, fatty acids, aromatic compounds, and phytochemicals (e.g., polyphenols) which can be extracted, purified, concentrated and used as functional ingredients in the food industry or other related sectors (De Camargo et al., 2018, Ben-Othman et al., 2020). The integration of pepper seed and pepper seed products as by-products in the food processing chain is a good example of the circular economy and a health-promoting way to meet the need for micronutrients and get better the quality of life (Jarret et al., 2013). Due to the growing consumer's solicitude for food safety, health, and environmental impact the aim of this paper is to provide an overview of EU legislation regarding the nutritional quality, safety and voluntary product labeling of pepper by-products before they are placed on the market. 


\section{Nutritional characteristics of the pepper by-products}

Peppers (Capsicum annuum L.) are vegetables used in the diet of people around the world. Annual global production in 2018. reached approximately 5.5 million tons (dried chilies and peppers (FAO, 2021). Like many fruits and vegetables, peppers are an excellent source of starch, dietary fiber, protein, lipids minerals, vitamins E, C and A, amino acids, carotenoids, phenolic compounds and polyunsaturated fatty acids (O'Sullivan et al., 2010, Sandoval-Castro et al., 2017, Echave et al., 2020). The level of nutritional and bioactive compounds differs depending on the pepper fruit part (placenta, pericarp, and seeds), the cultivar or variety, the ripening stage, the climatic and storage conditions as well as the manufacturing practices (Jayaprakasha et al., 2012). Phenolic acids and flavonoids are the main phenolic phytochemicals found in peppers. Phenolic compounds have positive effects on health and are currently in the spotlight of nutritional and pharmacological research. Not just the fruits but also the seeds of peppers are a potential source of bioactive compounds that may be used in the food industry (Silva et al., 2013). During the processing of peppers into processed food products e.g., ketchup and ajvar (a traditional relish of Balkan origin), by-products such as seeds, seed lodges (placenta), stalks are likely to be formed.

Numerous studies have been conducted in recent years that have revealed the nutritional and health benefits of red pepper seeds and their products (Socaci et al., 2017, Azabou et al., 2017, Baenas et al., 2019, Yilmaz et al., 2017). They are recognized for their antimicrobial, anticarcinogenic and antioxidant effects (Chouaibi et al., 2019). Pepper seed has a high percentage of dietary fiber and is a good source of protein and fatty acids (El-Safy et al., 2012, Cvetković et al., 2020). The oil content in pepper seeds is above $20 \%$, which means that it is promising for new products such oils and the products thereof. Red pepper seed oils are rich in polyunsaturated fatty acids, especially linoleic acids (Y1lmaz et al., 2015, Koncsek et al., 2018, Cvetković et al., 2020). Linoleic acid and $\alpha$-linolenic acid have been recognized as essential fatty acids and are precursors of other important fatty acids in metabolism (Chouaibi et al., 2019). The carotenoids found in pepper seed oils are zeaxanthin, $\beta$-cryptoxanthin, capsorubin, $\beta$-carotene, $\gamma$-carotene, cryptocapsin, lutein, lycopene. The composition of the total content of carotenoid pigments in the oil is an important quality parameter because it correlates with the color, which is the basic attribute for assessing the quality of the oil (Başyiğit et al., 2020). Since the contribution of phytochemicals changes with the metabolic and chemical processes, sampling and storage conditions should be controlled to produce plant material of suitably high quality for further use (Başyiğit et al., 2020). Pepper seed cake obtained from cold pressing seed oil is a good source of protein and some minerals and have functional properties such as water-holding capacity, emulsification and foaming abilities (Yilmaz et al., 2017). Also, according to literature data (Table 1), pepper seed flour is a nutritionally rich food due to significant amount of protein, dietary fiber, vitamins, minerals, and polyphenols, while pepper seed oil is rich in unsaturated fatty acids, especially linoleic and oleic acid, and vitamin E.

Some of the bioactive and nutritional components found in significant amounts in pepper seed flour and oil and their impact on human health are shown in the Table 1.

\section{EU food legislative framework}

All food intended for the human consumption must comply with general food laws and all relevant food safety regulations (Regulation (EC) 178/2002). Particular attention must be paid to legislation governing the field of food safety, food for special nutritional and medical needs, food supplements, novel foods, food additives, general labeling, as well as nutritional and health claims, if there are any (Table 2). Therefore, as food products intended for human consumption, processed pepper byproducts (pepper seed oil, pepper seed flour, pepper seed oil cake formed after pressing seed) need to comply with the legislation cited.

Table 1. Bioactive and nutritional components found in significant amounts in pepper seed oil and flour and their impact on human health (Source: Authors'own compilation).

\begin{tabular}{|c|c|c|}
\hline $\begin{array}{l}\text { Bioactive and nutritional } \\
\text { components }\end{array}$ & Impact on human health & References \\
\hline Protein & Plant proteins contribute to cholesterol lowering and can modulate gut microbiota. & Busnelli et al., 2018 \\
\hline Fibers & $\begin{array}{l}\text { Increasing the amount of fibre-rich food improves serum lipoprotein levels, lowers } \\
\text { blood pressure, improves blood glucose control in diabetics, helps with the weight } \\
\text { loss. People who consume abundant amounts of dietary fibres, compared to those with } \\
\text { minimal fibre intake, are at lower risk of developing stroke, hypertension, diabetes, } \\
\text { obesity and certain gastrointestinal diseases. }\end{array}$ & Anderson et al., 2009 \\
\hline Linoleic acid & $\begin{array}{l}\text { It is essential in the diet because it is incorporated into cell membranes and partici- } \\
\text { pates in the synthesis of compounds responsible for regulating blood pressure. They } \\
\text { are also considered beneficial for health because of their ability to reduce total choles- } \\
\text { terol and body fat. }\end{array}$ & Cvetković et al., 2020 \\
\hline Oleic acid & $\begin{array}{l}\text { It contributes to the reduction of systolic blood pressure, reduction of serum LDL } \\
\text { cholesterol, reduces the risk of developing type } 2 \text { diabetes, obesity. }\end{array}$ & $\begin{array}{l}\text { Karacor and Cam, } \\
2015\end{array}$ \\
\hline Vitamin E & $\begin{array}{l}\text { Due to the antioxidant properties of vitamin E, it acts in the fight against various } \\
\text { diseases such as atherosclerosis, oxidation stress, cancer. This vitamin has been found } \\
\text { to be effective against asthma, allergies and diabetes. }\end{array}$ & Rizvi et al., 2014 \\
\hline $\begin{array}{l}\text { Phenolic compounds/ } \\
\text { Phenolic acids }\end{array}$ & $\begin{array}{l}\text { Phenolic compounds can act as antioxidants, anticarcinogens, cardiopreventatives, as } \\
\text { antimicrobials, antiviral agents. They have a number of beneficial effects on health, } \\
\text { including cancer prevention, cardiovascular diseases, diabetes, neurogenerative dis- } \\
\text { eases; can have an anti-inflammatory effect. }\end{array}$ & $\begin{array}{l}\text { Shahidi et al., 2019, } \\
\text { Bento-Silva et al., } \\
2020\end{array}$ \\
\hline $\begin{array}{l}\text { Carote } \\
\text { noids }\end{array}$ & $\begin{array}{l}\text { Strong antioxidants, when introduced, protect the human body against harmful effects } \\
\text { of free radicals, i.e. substances that destroy or damage cell membranes; they thereby } \\
\text { reduce the risk of several chronic diseases (cardiovascular diseases, diabetes and } \\
\text { cancer). } \beta \text {-carotene is a precursor of vitamin A, an important component in the main- } \\
\text { tenance of skin health. }\end{array}$ & Socaci et al., 2017 \\
\hline
\end{tabular}


Regulation (EC) 396/2005 lays down provisions relating to maximum levels of pesticide residues in or on food and feed and defines maximum residue levels (MRLs) applicable to products of plant and animal origin, ensuring a high level of consumer protection. The regulation has defined MRLs for oilseeds and oilseed oil in the range from 0.01 to $0.1 \mathrm{mg} / \mathrm{kg}$, depending on the pesticide. These criteria could also be applied to pepper seeds and by extension to their products.

EFSA provides an annual report analyzing pesticide residue levels in food on the European market, where the analysis is based on data from official national control (Regulation (EC) 396/2005). Of the 91,015 analyzed samples in 2018, 95.5\% were below the maximum residue level (MRL), 4.5\% exceeded this level, of which $2.7 \%$ were non-compliant, e.g., samples that exceed the MRL after taking into account measurement uncertainties. The individual MRL overrun rate increased for some fruits and vegetables, including sweet peppers, where the increase (2018 vs. 2015) was from 1.2\% to $2.4 \%$. Furthermore, repeatedly found in sweet peppers are the unapproved pesticides chlorfenapyr and triadimefon in randomly chosen samples (Medina-Pastor and Triacchini, 2020). According to this information, a high risk of pesticides in pepper seed products is to be expected, therefore continuous monitoring and risk assessment are required.

Regulation (EC) 1881/2006 sets maximum levels for certain contaminants in foodstuffs to keep them at toxicologically acceptable levels (Regulation (EC) 1881/2006). The foodstuffs listed in the Annex must not be placed on the market when they contain any of the contaminants listed at a level exceeding the allowed maximum level. In the Regulations, with respect to oilseeds, oils and fats, the maximum permitted levels have been established for the following contaminants: aflatoxins, lead, sum of dioxins and dioxin-like PCBs, ben (a) pyrene and sum of ben (a) pyrene, 3-MCPD, cadmium, lead, etc. Pepper seeds and their products could also be included in this group.

Regulation (EC) No 2073/2005 harmonizes microbiological criteria in the EU, defines the acceptability of a product or a food lot and verifies the HACCP measures based on the absence or presence, or number of microorganisms, including parasites, and /or quantity of their toxins/metabolites

Table 2. An overview of general EU legislation referring to food (Source: Authors'own compilation)

\begin{tabular}{|c|c|c|}
\hline & Regulation & Features of Regulation \\
\hline \multirow[t]{4}{*}{$\begin{array}{l}\text { Food safety regula- } \\
\text { tions }\end{array}$} & $\begin{array}{l}\text { Regulation (EC) 178/2002 (with } \\
\text { amendments) laying down the general } \\
\text { principles and requirements of food law }\end{array}$ & $\begin{array}{l}\text { provides the basis for the assurance of a high level of protection of human } \\
\text { health and consumers' interest in relation to food } \\
\text { lays down the general principles governing food and feed in general, and } \\
\text { food and feed safety, at Community and national level. } \\
\text { applies to all stages of production, processing and distribution of food and } \\
\text { feed }\end{array}$ \\
\hline & $\begin{array}{l}\text { Regulation EC } 396 / 2005 \text { (with amend- } \\
\text { ments) on maximum residue levels of } \\
\text { pesticides in or on food (with amend- } \\
\text { ment) }\end{array}$ & $\begin{array}{l}\text { the need to ensure a high level of consumer protection and harmonized } \\
\text { Community provisions relating to maximum levels of pesticide residues in } \\
\text { or on food and feed of plant and animal origin }\end{array}$ \\
\hline & $\begin{array}{l}\text { Regulation (EC) 1881/2006 (with } \\
\text { amendments) setting maximum levels } \\
\text { for certain contaminants in foodstuffs }\end{array}$ & lays down the maximum levels of contaminants in food \\
\hline & $\begin{array}{l}\text { Regulation (EC) } 2073 / 2005 \text { (with } \\
\text { amendments) on microbiological crite- } \\
\text { ria for foodstuffs }\end{array}$ & $\begin{array}{l}\text { lays down the microbiological criteria for certain micro-organisms and the } \\
\text { implementing rules to be complied with by food business operators }\end{array}$ \\
\hline \multirow[t]{3}{*}{$\begin{array}{l}\text { Food quality and } \\
\text { labeling regulations }\end{array}$} & $\begin{array}{l}\text { Regulation (EC) } 1169 / 2011 \text { (with } \\
\text { amendments) on the provision of food } \\
\text { information to consumers }\end{array}$ & $\begin{array}{l}\text { provides the basis for the assurance of a high level of consumer protection } \\
\text { in relation to food information } \\
\text { establishes the general principles, requirements and responsibilities gov- } \\
\text { erning food information, and in particular food labelling } \\
\text { applies to food business operators at all stages of the food chain, where } \\
\text { their activities concern the provision of food information to consumers }\end{array}$ \\
\hline & $\begin{array}{l}\text { Regulation (EC) } 1925 / 2006 \text { (with } \\
\text { amendments) on the addition of vita- } \\
\text { mins and minerals and of certain other } \\
\text { substances to foods }\end{array}$ & $\begin{array}{l}\text {-harmonizes the provisions which relate to the addition of vitamins and } \\
\text { minerals and of certain other substances to foods } \\
\text {-the total amount of the vitamin or mineral present, for whatever purpose, } \\
\text { in the food as sold must not exceed the maximum amounts set in accord- } \\
\text { ance with the procedure }\end{array}$ \\
\hline & $\begin{array}{l}\text { Regulation (EC) 1924/2006 (with } \\
\text { amendments) on nutrition and health } \\
\text { claims made on foods } \\
\text { Regulation (EU) No 432/2012 (with } \\
\text { amendments) establishing a list of } \\
\text { permitted health claims made on foods, } \\
\text { other than those referring to the reduc- } \\
\text { tion of disease risk and to children's } \\
\text { development and health }\end{array}$ & $\begin{array}{l}\text { prescribes approved nutrition and health claims that may be placed on food } \\
\text { declarations } \\
\text { health claim means any claim that states, suggests or implies that a rela- } \\
\text { tionship exists between a food category, a food or one of its constituents } \\
\text { and health. } \\
\text { nutrition claim means any claim which states, suggests or implies that a } \\
\text { food has particular beneficial nutritional properties due to: the energy (cal- } \\
\text { orific value) it provides, provides at a reduced or increased rate, or does } \\
\text { not provide; and/or the nutrients or other substances it contains, contains in } \\
\text { reduced or increased proportions, or does not contain; }\end{array}$ \\
\hline
\end{tabular}


(Regulation (EC) 2073/2005). The regulation prescribes criteria only for high-risk foods, while national or international guidelines for microbiological criteria are to apply to other food groups, including pepper seed products.

Functional or bioactive compounds that are parts of vegetable byproducts, are not clearly regulated. However, any type of bioactive compound, added or naturally presented in food, may fall under one or more regulations. This can slow down the placing of new and innovative products on the market, so knowledge of the regulatory environment is a very important step in this process. Regulation (EU) 1169/2011 on the provision of food information to consumers establishes the legal framework in the European Union on information provided to consumers at all stages of the food chain. It defines the responsibilities for mandatory and optional information for food products. Under this regulation all packaged foods must have nutritional value declarations. Nutritional information includes information on energy value, amount of fat, saturated fat, carbohydrates, sugars, protein, and salt. Additionally, the following may be mentioned: the monounsaturates, polyunsaturates, polyols, starches, fibres and / or certain vitamins and minerals (Regulation (EC) 1169/2011).

Regulation (EC) No. 1925/2006 on the addition of essential nutrients to foods harmonizes the provisions laid down in member states that relate to the addition of vitamins and minerals and of certain other substances to foods (Regulation (EC) No. 1925/2006). There is a wide range of nutrients and other ingredients that might be used in food industry, such as various plants and herbal extracts, fibre, vitamins, minerals, amino acids, essential fatty acids, etc. Only vitamins or minerals prescribed by this Regulation can be added to the food products.

Food business operators can decide on putting voluntarily authorized claims on the label, but in this case the substance on the basis of which a nutrition or health claim is made must be declared. The amount of the substance(s) connected with specific claims must be stated in the 'same field of vision' with other nutrition information. Regulation (EC) No. 1924/2006 on nutrition and health claims made on foods harmonized rules for the use of nutrition. According to the regulation all claims that state, suggest or imply a relationship between food and health may be considered to be health claims (Regulation (EC) 1924/2006). Health claims about food should be scientifically supported and correctly interpreted, must be reliable and not mislead consumers. All health claims that can be used within the European Union and have passed the strictly prescribed approval procedure are entered in the Register of approved health claims available on the official website of the European Commission (Regulation (EU) No 432/2012). Health claims offer companies that produce functional food the opportunity to differentiate their products in markets, adding value to their products, thus strengthening the competitive position of their products (Moors, 2012, Hieke et al., 2015, De Roos et al., 2019).

Based on literature data on the bioactive components and nutrients found in significant quantities, to pepper seed products, such flour and oil, could be applied approved health claims listed in Table 3. There are not any approved health claims connected to carotenoids and polyphenolic compounds.

\section{Voluntary labeling of origin and sustainability}

Research has shown that consumers highly value food labeling schemes regulated by EU legislation and are willing to pay to get an authentic product (Gracia and de-Magistris, 2016). At the same time, there is an economic benefit for producers in terms of marketing and increasing the sales of certain products as well as a competitive advantage in the market (Velčovská, 2016). Examples of such logos are protected designation of origin (PDO), protected geographical indication (PGI) and traditional specialty guaranteed (TSG) (Regulation (EU) No 1151/2012, Regulation (EU) No 664/2014).

The organic or eco label can only be used on products that have been certified as organic by an authorized control agency or body. This means that they have fulfilled strict conditions on how they must be produced, processed, transported, and stored (European Union, 2020, Regulation (EU) No 664/2014, Regulation (EC) No 889/2008). Legislation on the organic and quality schemes are described in Table 4.

In the case of products obtained from pepper by-products, indications concerning the geographical origin and/or the method of cultivation may be placed on the product declaration, if the case (e.g., organic virgin pepper seed oil, cold extraction).

Grunert and authors (Grunert et al., 2014) have shown that despite a moderately high level of concern about the sustainability of food production in general, the use of environmental labels (Rainforest Alliance, Carbon Footprint) and ethical labels (Fair Trade, Animal Welfare) on food products is low. However, Carbon Footprint (total greenhouse gas emissions measure) and Animal Welfare labels were the most understandable.

In recent years, the label sustainable has been increasingly spotted, but it is not clear whether or to what extent it influences the decision to purchase the product. A study by Janßen and Langen, 2017 has divided consumers into three groups with respect to the intention to buy such products: "price-sensitive" (only the price is important regardless of the sustainable label), "label-choosers" (willing to pay more for the products with the sustainable label) and "price-conscious label discriminators" (if they are labeled together e.g., organic together with no genetically modified organisms or animal welfare, this gives a significant positive utility). Likewise, this study also showed that consumers are confused by the large number of sustainable labels and $85 \%$ of the market would be more satisfied with a universal sustainability label.

\section{Conclusions}

Pepper by-products (seed, seed lodges) that have been formed during processing other food products, are nutritionally valuable material for the development of new food products (e.g., pepper seed oil, pepper seed flour, pepper seed oil cake). Their possible being placed on the market as a valuable product or ingredient, is an opportunity for food producers to transform their product portfolio and move from a linear to a circular economy.

Before being placed on the market, food safety, quality and labeling of pepper by-products as a new manufactured product need to comply with the general food legislation.

The emphasis on geographical origin, cultivation (e.g., organic), special nutritional or functional properties through nutritional and health claims on the product label is voluntary, i.e. subject to the same rules as all other foods (if applicable).

However, food products made from by-products can be additionally declared through special logos related to sustainability, which is a motive for more and more consumers to buy. Due to the large number of various sustainability labels that are not yet regulated, manufacturers of such products must additionally educate consumers through social networks, websites or traditional media channels ( $\mathrm{TV}$, radio, newspapers) to help them understand logos and the concept of the circular economy. Although the transition to a circular economy is currently a challenge for industry, it seems to be the only way to save the planet, it is also an opportunity to attract new, sustainable conscious consumers and build a new reputation in social responsibility. 
Table 3. Authorized health claims for components found in pepper seed products (Source: Regulation (EU) No 432/2012) (Source: Authors'own compilation).

\begin{tabular}{|c|c|c|}
\hline $\begin{array}{l}\text { Nutrient, substance, food, } \\
\text { or food category }\end{array}$ & Claim & Conditions for claim using \\
\hline Protein & $\begin{array}{l}\text { Protein contributes to a growth in muscle } \\
\text { mass }\end{array}$ & $\begin{array}{l}\text { The claim may be used only for food which is at least a source of protein as referred } \\
\text { to in the claim SOURCE OF PROTEIN as listed in the Annex to Regulation (EC) No } \\
\text { 1924/2006 }\end{array}$ \\
\hline Protein & $\begin{array}{l}\text { Protein contributes to the maintenance of } \\
\text { muscle mass }\end{array}$ & $\begin{array}{l}\text { The claim may be used only for food which is at least a source of protein as referred } \\
\text { to in the claim SOURCE OF PROTEIN as listed in the Annex to Regulation (EC) No } \\
1924 / 2006 .\end{array}$ \\
\hline Protein & $\begin{array}{l}\text { Protein contributes to the maintenance of } \\
\text { normal bones }\end{array}$ & $\begin{array}{l}\text { The claim may be used only for food which is at least a source of protein as referred } \\
\text { to in the claim SOURCE OF PROTEIN as listed in the Annex to Regulation (EC) No } \\
\text { 1924/2006. }\end{array}$ \\
\hline $\begin{array}{l}\text { Non-digestible carbohy- } \\
\text { drates }\end{array}$ & $\begin{array}{l}\text { Consumption of foods/drinks contain- } \\
\text { ing }<\text { name of all used non-digestible } \\
\text { carbohydrates }>\text { instead of sugars induces } \\
\text { a lower blood glucose rise after their con- } \\
\text { sumption compared to sugar-containing } \\
\text { foods/drinks. }\end{array}$ & $\begin{array}{l}\text { In order to bear the claim, sugars should be replaced in foods or drinks by non-di- } \\
\text { gestible carbohydrates, which are carbohydrates neither digested nor absorbed in the } \\
\text { small intestine, so that foods or drinks contain reduced amounts of sugars by at least } \\
\text { the amount referred to in the claim REDUCED [NAME OF NUTRIENT] as listed in } \\
\text { the Annex to Regulation (EC) No 1924/2006. }\end{array}$ \\
\hline $\begin{array}{l}\text { Non-fermentable carbohy- } \\
\text { drates }\end{array}$ & $\begin{array}{l}\text { Consumption of foods/drinks contain- } \\
\text { ing < name of all used non-fermentable } \\
\text { carbohydrates }>\text { instead of fermentable } \\
\text { carbohydrates contributes to the mainte- } \\
\text { nance of tooth mineralization. }\end{array}$ & $\begin{array}{l}\text { In order to bear the claim, fermentable carbohydrates }\left(1^{* *}\right) \text { should be replaced in } \\
\text { foods or drinks by non-fermentable carbohydrates }\left(2^{* * *}\right) \text { in such amounts that con- } \\
\text { sumption of such foods or drinks does not lower plaque pH below } 5.7 \text { during and up } \\
\text { to } 30 \text { minutes after consumption. } \\
\left(1^{* *}\right) \text { Fermentable carbohydrates are defined as carbohydrates or carbohydrate } \\
\text { mixtures as consumed in foods or beverages that lower plaque } \mathrm{pH} \text { below } 5.7 \text {, as deter- } \\
\text { mined in vivo or in situ by plaque } \mathrm{pH} \text { telemetry tests, by bacterial fermentation during } \\
\text { and up to } 30 \text { minutes after consumption. } \\
\left(2^{* * *}\right) \text { Non-fermentable carbohydrates are defined as carbohydrates or carbohydrate } \\
\text { mixtures as consumed in foods or beverages that do not lower plaque } \mathrm{pH} \text {, as deter- } \\
\text { mined in vivo or in situ by plaque } \mathrm{pH} \text { telemetry tests, below a conservative value of } \\
5.7 \text { by bacterial fermentation during and up to } 30 \text { minutes after consumption. }\end{array}$ \\
\hline $\begin{array}{l}\alpha \text {-linolenic acid and } \\
\text { linoleic acid }\end{array}$ & $\begin{array}{l}\text { Essential fatty acids are needed for nor- } \\
\text { mal growth and development of children }\end{array}$ & $\begin{array}{l}\text { Information to the consumer that the beneficial effect is obtained with a daily intake } \\
\text { of } 2 \mathrm{~g} \text { of } \alpha \text {-linolenic acid (ALA) and a daily intake of } 10 \mathrm{~g} \text { of linoleic acid (LA). }\end{array}$ \\
\hline $\begin{array}{l}\text { Alpha-linolenic acid } \\
\text { (ALA) }\end{array}$ & $\begin{array}{l}\text { ALA contributes to the maintenance of } \\
\text { normal blood cholesterol levels }\end{array}$ & $\begin{array}{l}\text { The claim may be used only for food which is at least a source of ALA as referred } \\
\text { to in the claim SOURCE OF OMEGA-3 FATTY ACIDS as listed in the Annex to } \\
\text { Regulation (EC) No 1924/2006. } \\
\text { Information shall be given to the consumer that the beneficial effect is obtained with a } \\
\text { daily intake of } 2 \mathrm{~g} \text { of ALA. }\end{array}$ \\
\hline Linoleic acid & $\begin{array}{l}\text { Linoleic acid contributes to the mainte- } \\
\text { nance of normal blood cholesterol levels }\end{array}$ & $\begin{array}{l}\text { The claim may be used only for a food which provides at least } 1.5 \mathrm{~g} \text { of linoleic acid } \\
\text { (LA) per } 100 \mathrm{~g} \text { and per } 100 \mathrm{kcal} \text {. } \\
\text { Information shall be given to the consumer that the beneficial effect is obtained with a } \\
\text { daily intake of } 10 \mathrm{~g} \text { of LA. }\end{array}$ \\
\hline Oleic acid & $\begin{array}{l}\text { Replacing saturated fats in the diet with } \\
\text { unsaturated fats contributes to the mainte- } \\
\text { nance of normal blood cholesterol levels. } \\
\text { Oleic acid is an unsaturated fat. }\end{array}$ & $\begin{array}{l}\text { The claim may be used only for food, which is high in unsaturated fatty acids, as } \\
\text { referred to in the claim HIGH UNSATURATED FAT as listed in the Annex to Regula- } \\
\text { tion (EC) No 1924/2006. }\end{array}$ \\
\hline Vitamin E & $\begin{array}{l}\text { Vitamin E contributes to the protection of } \\
\text { cells from oxidative stress }\end{array}$ & $\begin{array}{l}\text { The claim may be used only for food which is at least a source of vitamin E as re- } \\
\text { ferred to in the claim SOURCE OF [NAME OF VITAMIN/S] AND/OR [NAME OF } \\
\text { MINERAL/S] as listed in the Annex to Regulation (EC) No 1924/2006. }\end{array}$ \\
\hline $\begin{array}{l}\text { Foods with a low or re- } \\
\text { duced content of saturated } \\
\text { fatty acids }\end{array}$ & $\begin{array}{l}\text { Reducing consumption of saturated fat } \\
\text { contributes to the maintenance of normal } \\
\text { blood cholesterol levels }\end{array}$ & $\begin{array}{l}\text { The claim may be used only for food which is at least low in saturated fatty acids, as } \\
\text { referred to in the claim LOW SATURATED FAT } \\
\text { or reduced in saturated fatty acids as referred to in the claim } \\
\text { REDUCED [NAME OF NUTRIENT] as listed in the Annex to Regulation (EC) No } \\
\text { 1924/2006. }\end{array}$ \\
\hline $\begin{array}{l}\text { Monounsaturated and/ } \\
\text { or polyunsaturated fatty } \\
\text { acids }\end{array}$ & $\begin{array}{l}\text { Replacing saturated fats with unsaturated } \\
\text { fats in the diet contributes to the mainte- } \\
\text { nance of normal blood cholesterol levels } \\
\text { [MUFA and PUFA are unsaturated fats] }\end{array}$ & $\begin{array}{l}\text { The claim may be used only for food which is high in unsaturated fatty acids, as } \\
\text { referred to in the claim HIGH UNSATURATED FAT as listed in the Annex to Regula- } \\
\text { tion (EC) No 1924/2006. }\end{array}$ \\
\hline $\begin{array}{l}\text { Foods with a low or } \\
\text { reduced content of sodium }\end{array}$ & $\begin{array}{l}\text { Reducing consumption of sodium } \\
\text { contributes to the maintenance of normal } \\
\text { blood pressure }\end{array}$ & $\begin{array}{l}\text { The claim may be used only for food which is at least low in sodium/salt as referred } \\
\text { to in the claim LOW SODIUM/SALT } \\
\text { or reduced in sodium/salt as referred to in the claim } \\
\text { REDUCED [NAME OF NUTRIENT] as listed in the Annex to Regulation (EC) No } \\
\text { 1924/2006. }\end{array}$ \\
\hline Vitamin E & $\begin{array}{l}\text { Vitamin E contributes to the protection of } \\
\text { cells from oxidative stress }\end{array}$ & $\begin{array}{l}\text { The claim may be used only for food which is at least a source of vitamin E as re- } \\
\text { ferred to in the claim SOURCE OF [NAME OF VITAMIN/S] AND/OR [NAME OF } \\
\text { MINERAL/S] as listed in the Annex to Regulation (EC) No 1924/2006. }\end{array}$ \\
\hline
\end{tabular}


Table 4. EU legislation referring to organic food and quality schemes (Source: Authors'own compilation).

\begin{tabular}{|l|l|l|}
\hline & Regulation & Features of Regulation \\
\hline $\begin{array}{l}\text { Quality schemes } \\
\text { regulations }\end{array}$ & $\begin{array}{l}\text { Regulation (EU) No 1151/2012 of the European } \\
\text { Parliament and of the Council of 21 November } \\
2012 \text { on quality schemes for agricultural prod- } \\
\text { ucts and foodstuffs }\end{array}$ & $\begin{array}{l}\text { establishes quality schemes that provide the basis for the identi- } \\
\text { fication and, where appropriate, protection of names and terms } \\
\text { that indicate or describe agricultural products } \\
\text { helps producers of agricultural products and foodstuffs to com- } \\
\text { municate the product characteristics and farming attributes of } \\
\text { those products and foodstuffs to buyers and consumers }\end{array}$ \\
\hline & $\begin{array}{l}\text { Commission delegated Regulation (EU) No } \\
664 / 2014 \text { supplementing Regulation (EU) No } \\
1151 / 2012\end{array}$ & $\begin{array}{l}\text { supplementing Regulation (EU) No 1151/2012 of the European } \\
\text { Parliament and of the Council regarding the establishment of the } \\
\text { Union symbols for protected designations of origin, protected } \\
\text { geographical indications and traditional specialties guaranteed } \\
\text { and regarding certain rules on sourcing, certain procedural rules } \\
\text { and certain additional transitional rules }\end{array}$ \\
\hline & $\begin{array}{l}\text { Commission implementing Regulation (EU) No } \\
668 / 2014 \text { laying down rules for the application } \\
\text { of Regulation (EU) No 1151/2012 }\end{array}$ & $\begin{array}{l}\text { laying down rules for the application of Regulation (EU) No } \\
1151 / 2012 \text { of the European Parliament and of the Council on } \\
\text { quality schemes for agricultural products and foodstuffs }\end{array}$ \\
\hline $\begin{array}{l}\text { Organic food } \\
\text { regulations }\end{array}$ & $\begin{array}{l}\text { Council Regulation (EC) No 834/2007 of on } \\
\text { organic production and labelling of organic } \\
\text { products and repealing Regulation (EEC) No } \\
\text { 2092/91 }\end{array}$ & $\begin{array}{l}\text { provides the basis for the sustainable development of organic } \\
\text { production while ensuring the effective functioning of the inter- } \\
\text { nal market, guaranteeing fair competition, ensuring consumer } \\
\text { confidence and protecting consumer interests }\end{array}$ \\
\hline
\end{tabular}

\section{References}

Anderson J. W., Baird P., Davis R. H., Ferreri S., Knudtson,M., Koraym A., Waters V., Williams C. L. (2009) Health benefits of dietary fiber. Nutrition reviews, 67 (4) 188-205.

Azabou S., Taheur F. B., Jridi M., Bouaziz M., Nasri M. (2017) Discarded seeds from red pepper (Capsicum annum) processing industry as a sustainable source of high added-value compounds and edible oil. Environmental Science and Pollution Research, 24 (28) $22196-22203$.

Baenas N., Belović M., Ilic N., Moreno D. A., García-Viguera C. (2019) Industrial use of pepper (Capsicum annum L.) derived products: Technological benefits and biological advantages. Food Chemistry, 274 872-885.

Başyiğit B., Dağhan Ş., Karaaslan M. (2020) Biochemical, compositional, and spectral analyses of Isot (Urfa pepper) seed oil and evaluation of its functional characteristics. Grasas Aceites, 71 (4) e384.

Ben-Othman S., Jõudu I., Bhat R. (2020) Bioactives from agri-food wastes: Present insights and future challenges. Molecules, 25 (3) 510.

Bento-Silva A., Koistinen V. M., Mena P., Bronze M. R., Hanhineva K., Sahlstrøm S., Kitrytė V., Moco S., Aura A. M. (2020) Factors affecting intake, metabolism and health benefits of phenolic acids: do we understand individual variability?. European Journal of Nutrition, 59 (4) $1275-1293$.

Busnelli M., Manzini S., Sirtori C. R., Chiesa G., Parolini C. (2018) Effects of vegetable proteins on hypercholesterolemia and gut microbiota modulation. Nutrients, 10 (9) 1249.

Chouaibi M., Rezig L., Hamdi S., Ferrari G. (2019) Chemical characteristics and compositions of red pepper seed oils extracted by different methods. Industrial Crops and Products, 128 363-370.

Commission delegated Regulation(EU) No 664/2014 of 18 December 2013 supplementing Regulation(EU) No 1151/2012 of the European Parliament and of the Council with regard to the establishment of the Union symbols for protected designations of origin, protected geographical indications and traditional specialties guaranteed and with regard to certain rules on sourcing, certain procedural rules and certain additional transitional rules. Official Journal of the European Union, L 179/17.

Commission implementing Regulation (EU) No 668/2014 of 13 June 2014 laying down rules for the application of Regulation (EU) No 1151/2012 of the European Parliament and of the Council on quality schemes for agricultural products and foodstuffs. Official Journal of the European Union, L 179/36.

Commission Regulation (EC) No 1881/2006 of 19 December 2006 setting maximum levels for certain contaminants in foodstuffs, Official Journal of the European Union, L 364/5.

Commission Regulation (EC) No 2073/2005 of 15 November 2005 on microbiological criteria for foodstuffs, Official Journal of the European Union, L 338/1.

Commission Regulation (EC) No 889/2008 of 5 September 2008 laying down detailed rules for the implementation of Council Regulation (EC) No $834 / 2007$ on organic production and labelling of organic products with regard to organic production, labelling and control. Official Journal of the European Union, L 250/1

Commission Regulation (EU) No 432/2012 of 16 May 2012 establishing a list of permitted health claims made on foods, other than those referring to the reduction of disease risk and to children's development and health. Official Journal of the European Union, L 136/1.

Council Regulation (EC) No 834/2007 of 28 June 2007 on organic production and labelling of organic products and repealing Regulation (EEC) No 2092/91. Official Journal of the European Union, L 189/1.

Cvetković T., Ranilović J., Gajari D., Tomić-Obrdalj H., Šubarić D., Moslavac T., Cikoš A. M., Jokić S. (2020) Podravka and Slavonka Varieties of 
Pepper Seeds (Capsicum annuum L.) as a New Source of Highly Nutritional Edible Oil. Foods, 9 (9) 1262.

De Camargo A. C., Schwember A. R., Parada R., Garcia S., Marostica Junior M. R., Franchin M., Regitano-d'Arce M. A. B., Shahidi F. (2018) Opinion on the hurdles and potential health benefits in value-added use of plant food processing by-products as sources of phenolic compounds. International Journal of Molecular Sciences, 19 (11) 3498.

De Roos B., Aura A. M., Bronze M., Cassidy A., Garcia Conesa M.-T., Gibney E. R., Greyling A., Kaput J., Kerem Z., Knežević N., Kroon P., Landberg R., Manach C., Milenkovic D., Rodriguez-Mateos A., Tomás-Barberán F. A. (2019) Targeting the delivery of dietary plant bioactives to those who would benefit most: from science to practical applications. European Journal of Nutrition, 58 65-73.

Echave J., Pereira A. G., Carpena M., Prieto M. Á., Simal-Gandara J. (2020) Capsicum seeds as a source of bioactive compounds: biological properties, extraction systems, and industrial application. In: Dekebo A. (ed): Capsicum, IntechOpen Publishing.

El-Safy F. S., Salem R. H., Abd El-Ghany M. E. (2012) Chemical and Nutritional Evaluation of Different Seed Flours as Novel Sources of Protein. World Journal of Dairy \& Food Sciences, 7 (1) 59-65.

European Commission (2020) Communication from the Commission to the European Parliament, the Council, the European Economic and Social Committee and the Committee of the Region, COM (2020) 98 final. Available at: https://eur-lex.europa.eu/legal-content/EN/ TXT/?qid=1583933814386\&uri=COM:2020:98:FIN Accessed: 01.10.2021.

European Union (2020) Study on economic value of EU quality schemes, geographical indications (GIs) and traditional specialties guaranteed (TSGs). Luxembourg: Publications Office of the European Union, 2020.

Food and Agriculture Organization (FAO) (2021) FAOSTAT Value of Agricultural Production. Available at: https://www.fao.org/faostat/en/\#data/QV/ visualize Accessed: 20.12.2021.

Gracia A., de-Magistris T. (2016) Consumer preferences for food labeling: what ranks first? Food Control, 61 39-46.

Grunert K.G., Hieke S., Wills J (2014) Sustainability labels on food products: Consumer motivation, understanding and use. Food Policy, 22 177-189. Hieke S., Kuljanic N., Wills J. M., Pravst I., Kaur A., Raats M. M., van Trijp H. C. M., Verbeke, W., Grunert K. G. (2015) The role of health-related claims and health-related symbols in consumer behaviour: Design and conceptual framework of the CLYMBOL project and initial results. Nutrition Bulletin, 40 (1) 66-72.

Janßen D., Langen N. (2017) The bunch of sustainability labels - Do consumers differentiate? Journal of Cleaner Production, 143 1233-1245.

Jarret R. L., Levy I. J., Potter T. L., Cermak S. C. (2013) Seed oil and fatty acid composition in Capsicum spp. Journal of Food Composition and Analysis, 30 102-108.

Jayaprakasha G. K., Bae H., Crosby K., Jifon J. L., Patil B. S. (2012) Bioactive compounds in peppers and their antioxidant potential. Hispanic Foods: Chemistry and Bioactive Compounds, 1109 43-56.

Karacor K., Cam M. (2015) Effects of oleic acid. Medical Science and Discovery, 2 (1) 125-132.

Koncsek A., Helyes L., Daood H. G. (2018) Bioactive compounds of cold pressed spice paprika seeds oils. Journal of Food Processing and Preservation, 42 (1) e13403.

Medina-Pastor P., Triacchini G. (2020) The 2018 European Union report on pesticide residues in food. EFSA Journal, 18 (4) 6057.

Moors E. H. (2012) Functional foods: regulation and innovations in the EU. Innovation: The European Journal of Social Science Research, 25 (4) 424-440.

NASA (2021) Global climate change. Available at: https://climate.nasa.gov Accessed: 1.10.2021.

Notarnicola B., Tassielli G., Renzulli P.A., Castellani V., Sala S. (2017) Environmental impacts of food consumption in Europe. Journal of Cleaner Production, 140 753-765.

O’Sullivan L., Jiwan M. A., Daly T., O’Brien N. M., Aherne S. A. (2010) Bioaccessibility, uptake, and transport of carotenoids from peppers (Capsicum spp.) using the coupled in vitro digestion and human intestinal Caco-2 cell model. Journal of agricultural and food chemistry, 58 (9) $5374-5379$.

Regulation (EC) No 178/2002 of the European Parliament and of the Council of 28 January 2002 laying down the general principles and requirements of food law, establishing the European Food Safety Authority and laying down procedures in matters of food safety, Official Journal of the European Communities, L 31/1.

Regulation (EC) No 1924/2006 of the European Parliament and of the Council of 20 December 2006 on nutrition and health claims made on foods, Official Journal of the European Union, L 404/9.

Regulation (EC) No 1925/2006 of the European Parliament and of the Council of 20 December 2006 on the addition of vitamins and minerals and of certain other substances to foods, Official Journal of the European Union, L 404/26.

Regulation (EC) No 396/2005 of the European Parliament and of the Council of 23 February 2005 on maximum residue levels of pesticides in or on food and feed of plant and animal origin and amending Council Directive 91/414/EEC. Official Journal of the European Union, L 70/1.

Regulation (EU) No 1151/2012 OF THE European Parliament and of the Council of 21 November 2012 on quality schemes for agricultural products and foodstuffs. Official Journal of the European Union, L 343/1.

Regulation (EU) No 1169/2011 of the European Parliament and of the Council of 25 October 2011 on the provision of food information to consumers, amending Regulations (EC) No 1924/2006 and (EC) No 1925/2006 of the European Parliament and of the Council, and repealing Commission Directive 87/250/EEC, Council Directive 90/496/EEC, Commission Directive 1999/10/EC, Directive 2000/13/EC of the European Parliament and of the Council, Commission Directives 2002/67/EC and 2008/5/EC and Commission Regulation (EC) No 608/2004, Official Journal of the European Union, L 304/18.

Rizvi S., Raza S. T., Faizal Ahmed A. A., Abbas S., Mahdi F. (2014) The role of vitamin E in human health and some diseases. Sultan Qaboos University Medical Journal, 14 (2) e157.

Sandoval-Castro C. J., Valdez-Morales M., Omah B. D., Gutierrez-Dorado R., Medina-Godoy S., Espinosa-Alonso L. G. (2017) Bioactive compounds and antioxidant activity in scalded Jalapeno pepper industrial byproduct (Capsicum annuum). Journal of Food Science and Technology, 54 (7) 1999-2010.

Shahidi F., Varatharajan V., Oh W. Y., Peng H. (2019) Phenolic compounds in agri-food by-products, their bioavailability and health effects. Journal of Food Bioactives, 5 (1) 57-119.

Sijtsema J. S., Snoek H. M., van Haaster-de Winter M. A., Dagevos H. (2020) Let's talk about Circular Economy: A Qualitative Exploration of Consumer Perceptions. Sustainability, 12 (1) 286.

Silva L. R., Azevedo J., Pereira M. J., Valentão P., Andrade P. B. (2013) Chemical assessment and antioxidant capacity of pepper (Capsicum annuum L.) seeds. Food and Chemical Toxicology, 53 240-248. 
Socaci S. A., Farcas A. C., Vodnar D. C. Tofana, M. (2017) Food wastes as valuable sources of bioactive molecules. In: Shiomi N, Waisundara V. (ed): Superfood and Functional Food-The Development of Superfoods and Their Roles as Medicine, pp.75-93. IntechOpen Publishing, Rijeka, Croatia. Stegmann P., Londo M., Junginger M. (2020) The circular bioeconomy: Its elements and role in European bioeconomy clusters. Resources, Conservation \& Recycling X, 6100029.

United Nations (2021) Shifting to a Circular Economy Essential to Achieving Paris Agreement Goals. Available at: https://unfccc.int/news/shiftingto-a-circular-economy-essential-to-achieving-paris-agreement-goals. Accessed: 15.9.2021.

Velčovská Š. (2016) Food quality labels from the producers' perspective. Journal of Central European Agriculture, 17 (3) 815-834.

Y1lmaz E., Arsunar E. S., Aydeniz B., Guneser O. (2015) Cold pressed capia pepperseed (Capsicum Annuum L.) oils: Composition, aroma, and sensory properties. European Journal of Lipid Science and Technology, 117 (7) 1016-1026.

Yilmaz E., Hüriyet Z., Arifoğlu N., Dünder Emir D. (2017) Functional Properties of the Capia Pepper Seed Defatted Press Cakes. Waste and Biomass Valorization, 8 (3) 783-791. 